JJPPUMA: Jurnal Ilmu Pemerintahan dan Sosial Politik UMA (Journal of Governance and Political Social UMA), 7 (1) (2019): 60-70

JPPUMA: Jurnal Ilmu Pemerintahan dan Sosial Politik UMA

(Journal of Governance and Political Social UMA)

DOI: http://dx.doi.org/10.31289/ippuma.v7i1.2000

Available online http://ojs.uma.ac.id/index.php/jppuma

\title{
Konstruksi Indikator dan Formula Penilaian Kualitas Pemilihan Umum di Indonesia
}

\section{Indonesian Election Quality Assessment in Realizing Quality Elections}

\author{
Lati Praja Delmana'), Aidinil Zetra ${ }^{2),}$ \& Alfan Miko ${ }^{3)}$ \\ 1) Pasca Sarjana Jurusan Ilmu Komunikasi, Konsentrasi Tata Kelola Pemilu, \\ Fakultas Ilmu Sosial dan Ilmu Politik, Universitas Andalas, Indonesia \\ 2) Pasca Sarjana Jurusan Ilmu Politik, Fakultas Ilmu Sosial Dan Ilmu Politik, \\ Universitas Andalas, Indonesia \\ 3) Jurusan Sosiologi, Fakultas Ilmu Politik Sosial dan Ilmu Politik, \\ Universitas Andalas, Indonesia \\ Diterima: November 2018; Disetujui: Februari 2019; Dipublish: Juni 2019.
}

\begin{abstract}
Abstrak
Pemilihan umum di Indonesia yang dilaksanakan sejak tahun 1955 berjalan tanpa memiliki alat ukur dan indikator kualitas Pemilu yang jelas. Peningkatkan kualitas pemilu merupakan salah satu kunci mewujudkan demokrasi berkualitas. Indikator standar dan penilaian kualitas pemilu pada penelitian terdahulu tidak mampu merepresentasikan prinsip nilai demokrasi Pancasila, nilai budaya politik lokal, dan kondisi masyarakat Indonesia yang heterogen, sehingga perlu adanya kajian khusus yang meperbaiki standar kualitas Pemilu sesuai dengan keadaan di Indonesia. Tujuan penelitian ini adalah untuk mengembangkan indikator dan instrumen penilaian kualitas pemilu nasional di Indonesia. Metode penelitian yang digunakan adalah studi kepustakaan didukung oleh hasil penelitian yang relevan. Indikator penilaian kualitas pemilu dibangun melalui seluruh aspek proses tata kelola pemilu pra, masa dan pasca pemilu. Keseluruhan aspek tersebut memenuhi prinsip kesetaraan, kebebasan, keadilan, transparansi, profesionalitas, keamanan, integritas dan penyesuaian budaya politik lokal. Penilaian kualitas pemilu dapat dilakukan melalui metode jejak pendapat dan diukur dengan skala pengukuran ordinal. Standarisasi Indeks kualitas pemilu nasional yang dibentuk dan dikembangkan sesuai dengan perkembangan zaman, menjamin keakuratan pengukuran kualitas pemilu, sehingga kualitas pemilu dapat diperbaiki secara berkelanjutan dan konsisten.
\end{abstract}

Kata kunci : Kualitas Pemilu, Pemilihan Umum Indonesia, Penilaian Pemilu

Abstract
General elections in Indonesia that have been carried out since 1955 have proceeded without having clear election quality indicators and indicators. Improving the quality of elections is one of the keys to realizing quality democracy. Standard indicators and evaluations of the quality of elections in previous studies were not able to represent the principles of Pancasila democratic values, local political cultural values, and heterogeneous conditions of Indonesian society, so special studies were needed to improve election quality standards in accordance with conditions in Indonesia. The purpose of this study is to develop indicators and instruments for assessing the quality of National Elections in Indonesia. The research method used is library research supported by the results of relevant research. Indicators for evaluating the quality of elections are built through all aspects of the pre, post and post-election governance process. All aspects meet the principles of equality, freedom, justice, transparency, professionalism, security, integrity and adjustment of local political culture. Assessment of election quality can be carried out through the opinion trail method and measured by ordinal measurement scale. Standardization The national election quality index established and developed in accordance with the times, guarantees the accuracy of measuring the quality of elections, so that the quality of elections can be improved on an ongoing and consistent basis.

Keywords: Election Quality, Election Indonesia, Assesment Election.

How to Cite: Lati Praja Delmana1), Aidinil Zetra2), \& Indraddin2) (2019). Konstruksi Indikator dan Formula Penilaian Kualitas Pemilihan Umum di Indonesia. JPPUMA: Jurnal Ilmu Pemerintahan dan Sosial Politik UMA (Journal of Governance and Political Social UMA), 7 (1): 60-70

*Corresponding author: ISSN 2549-1660 (Print)

E-mail: latipraja.d@gmail.com ISSN 2550-1305 (Online) 


\section{PENDAHULUAN}

Kualitas pemilu merupakan salah satu indikator kesuksesan demokrasi. Kualitas dan integritas pemilu merupakan satu kesatuan yang tidak dapat dipisahkan, penyelenggaraan pemilu berintegritas merupakan syarat mutlak terwujudnya Pemilu berkualitas. Pemilu berkualitas dapat dinilai dari proses tata kelola pemilu (Mozzafar dan Schelder,2002). Berbagai indikator kualitas pemilu yang dibangun oleh studi terdahulu dipengaruhi oleh perspektif peneliti dalam memecahkan persoalan pemilu di negaranya, sehingga parameter untuk setiap indikator harus disesuaikan dengan kondisi lingkungan dan budaya negara setempat.

Berikut Indikator kualitas pemilu menurut studi terdahulu, Pertama International Institute For Democracy And Electoral Assistance (IDEA) membangun 15 indikator yaitu menyusun kerangka hukum, sistem pemilihan umum, penetapan batasan, distrik dan definisi batasan pemilu unit, hak untuk memilih dan dipilih, badan pelaksana pemilu, pendaftaran pemilih dan daftar pemilih, akses surat suara bagi partai politik dan kandidat, kampanye pemilu yang demokratis, akses media dan kebebasan ekspresi, pembiayaan dan pengeluaran kampanye, pemungutan suara, penghitungan dan mentabulasikan suara, peranan perwakilan partai dan kandidat, pemantau pemilu dan kepatuhan terhadap penegakan Undang-Undang pemilu.

Kedua, menurut Eklit \& Reynolds (2005) terdapat 11 indikator kualitas pemilu, yaitu: regulasi, kualitas penyelenggara, konstituensi, pendidikan pemilih, penyusunan DPT, lokasi TPS, aturan kampanye, partisipasi pemilih, proses penghitungan suara, penyelesaian sengketa, dan audit hasil pemilu.

Ketiga, Lembaga Penelitian

Pendidikan Penerangan Ekonomi Sosial (LP3S) Indikator dibangun oleh LP3ES adalah integritas dan kualitas Tim Seleksi, Komisioner, Penyelenggara Ad-hoc. persentase penggunaan hak pemilih, kandidat berkualitas, logistik yang berkualitas dan akurat, daftar pemilih yang lengkap, tepat, dan akurat, kampanye yang adil dan bersih, Pemungutan suara yang transparan, akurat dan bersih, rekapitulasi yang akurat dan Penetapan Hasil dan penyelesaian sengketa Pemilu.

Kekurangan dari indikator studi terdahulu adalah Pertama, terdapat permasalahan pemilu penting yang tidak dibahas oleh IDEA yang sering menjadi permasalahan pemilu di Indonesia yaitu kualitas pengadaan dan distribusi logistik, pemenuhan prinsip kebebasan dan keadilan hak-hak minoritas dan penyandang disabilitas dalam proses kandidasi dan pendaftaran calon partai politik, audit pemilihan umum dan penyelesaian sengketa, perencanaan dan penganggaran pemilu. Kedua, Penelitian Eklit \& Reynolds (2005) juga tidak membangun indikator kualitas logistik pemilu, pemenuhan hak politik masyarakat.

Ketiga, indikator yang dibangun oleh LP3ES hanya berfokus kepada kualitas komisioner dan adhoc sedangkan kualitas sekretariat diabaikan. Selain itu, hak politik masyarakat tidak dikaji dengan lengkap karena hanya membahas tentang penggunaan hak memilih tapi tidak hak untuk dipilih.

Berdasarkan keterbatasan penelitian sebelumnya dan karena Indonesia belum memiliki alat ukur kualitas pemilu maka perlu dibuat standar kualitas pemilu nasional berdasarkan pengembangan standar kualitas pemilu studi terdahulu. Selama ini KPU menilai kualitas pemilu berdasarkan pendekatan formal dan substansial. Secara formal berpedoman kepada aturan terkait penyelenggaraan Pemilu, yaitu Undang-undang nomor 7 Tahun 2017 tentang Pemilu dan Peraturan Komisi Pemilihan Umum (PKPU) nomor 32 Tahun 2018 tentang Tahapan program dan jadwal penyelenggaraan pemilu tahun 2019, dan PKPU nomor 21 dan 22 tahun 
2018 tentang pencalonan peserta pemilu dan aturan terkait pemilu lainnya. Sedangkan secara substansial, berpedoman pada azaz pemilu yaitu mandiri, jujur, adil, kepastian hukum, tertib, kepentingan umum, keterbukaan, proporsionalitas, profesionalitas, akuntabilitas, efisiensi dan efektifitas. Sedangkan prinsip pemilu adalah langsung, umum, bebas dan rahasia.

Indikator dibangun IDEA (2001), LP3S dan Eklit\& Reynold (2005) tersebut belum mampu untuk merepresentasikan kualitas pemilu nasional di Indonesia karena tidak memiliki indikator yang menampung permasalahan pemenuhan hak politik masyarakat dalam hal kaum monoritas dan disabilitas, kualitas dan keamanan logistik, perencanaan dan penganggaran pemilu.

Kajian penelitian terdahulu yang dilakukan IDEA (2001), Mozzafar \&Schelder (2002), Eklit \& Reynold (2005), Afrobarometer (2007), Carter (2010), Carter (2014), The Ace Electoral Knowledge Network (2014), Sehat (2015), Lembaga Penelitian Pendidikan Penerangan Ekonomi Sosial (2014) secara garis besar memiliki kesamaan yaitu menggunakan prinsip kebebasan, kesetaraan dalam proses pelaksanaan pemilu.

Penelitian Eklit dan Reynold (2005) melihat kualitas pemilu dari proses tata kelola Pemilu pra, masa dan pasca pemilihan sedangkan menurut Mozzafar dan Schelder berfokus kepada kualitas pemilu dalam pembuatan, penerapan dan putusan pengadilan. Hal yang berbeda diungkapkan oleh Carter mengkaji kualitas pemilu dari segi malpraktek pemilu dan The Ace mengukur kualitas pemilu dengan instrumen kuantitatif dan kualitatif dengan alat ukur integritas.

Selain itu penelitian yang berbeda dikemukakan oleh Rexha (2016) bahwa untuk menjaga kualitas Pemilu perlu adanya umpan balik dari Pemilih dengan menjaga kualitas proses Pemilu dengan metode crowdsourching. Hal yang berbeda juga dikemukakan oleh Darnolf (2015), bahwa kualitas Pemilu bergantung pada kapasitas otoritas pemilihan dan kepercayaan publik terhadap lembaga, beberapa tingkat dukungan teknis dan keuangan internasional.

Sedangkan menurut Hirano dkk (2014), menyatakan bahwa peningkatan kualitas pemilu dimulai dari nilai prapemilu. Kajian kualitas Pemilu di Indonesia oleh Badan Pengawas Pemilihan Umum Republik Indonesia tahun 2014, 2015 dan 2018. Laporan Hasil Pengawasan Pemilu Presiden dan Wakil Presiden tahun 2014 mengkaji pengawasan secara partisipasif, bahwa dalam melihat kualitas Pemilu Bawaslu melalui pengawasan tahapan penetapan peserta pemilu, pendaftaran pemilih, logistik, kampanye, pemungutan dan perhitungan suara, Pilpres di luar negri dan pelanggaran dan penganan Pemilu Presiden dan Wakil Presiden. Sedangkan LP3S mengkaji kualitas pemilu berdasarkan tata kelola Pemilu dengan menggunakan prinsip integritas, independensi, profesionalitas, kinerja kebijakan, kualitas SDM dan pengelolaan keuangan Penyelenggara.

Kajian tersebut hanya mengakomodir permasalahan kualitas Pemilu di Sumatera Utara, Papua dan Maluku dan tidak mengkaji kualitas selama proses masa pra, pelaksanaan dan pasca pemilihan. Permasalahan tersebut yaitu pertama, terdapat 8 kasus penyelenggara adhoc yang dilantik menjelang pemungutan suara pada pemilu 2014 di 2 kasus di Sumatera Utara, 2 kasus di Maluku, 4 kasus di Papua pada Pemilu tahun 2014 yang mengindikasikan kurangnya profesionalitas penyelenggara adhoc, Kedua, terdapat 6 kasus indikasi ketidak netralan penyelenggara di Sumatera Utara, keterlambatan pengadaan dan distribusi logistik di NTT dan Papua. Ketiga, pengamanan logsitik di Kabupaten Sika dan 25 kasus politik uang di Sumatera Utara, Maluku dan Papua. 
Penelitian LP3S tersebut hanya fokus pada permasalahan pemilu tahun $2014 \mathrm{di}$ Maluku, Sumatera Utara, dan Papua sehingga tidak mewakili pemilu secara nasional di Indonesia. Kajian penelitian ini berbeda dengan penelitian sebelumnya, karena mengembangkan indikator baru menyesuaikan dengan kebutuhan di Indonesia.

Seperti telah disampaikan sebelumnya bahwa indikator yang ditawarkan oleh IDEA (2001) berjumlah 15 sedangkan Eklit \& Reynolds (2005) berjumlah 11. Indikator tersebut hanya berfokus kepada hak memilih warga, tapi hak untuk dipilih yang memenuhi prinsip keadilan terhadap kaum minoritas dan disabilitas belum dipenuhi. Selain itu penelitian Eklit \& Reynolds (2005) membangun indikator kualitas pemilu negara demokrasi mapan dan tidak mapan namun tidak menyesuaikan dengan kebutuhan lokal yang memiliki sistem pemilu yang berbeda, sehingga perlu adanya tambahan indikator sistem pemilu yang mewakili perempuan, kaum minoritas dan disabilitas.

Permasalahan lain yang belum tertuang dalam indikator kualitas pemilu sebelumnya adalah masalah perencanaan dan anggaran, kualitas dan kemanan logistik serta audit dan laporan hasil pemilu juga luput dari indikator yang dibangun.

Maka indikator dalam penelitain ini dikembangkan menjadi 17 indikator yaitu: Kerangka Hukum, Sistem Pemilu, Pembentukan badan penyelenggara pemilu, Perencanan Program dan Anggaran, Sosialisasi, Pembentukan dan Penyelenggaraan Partai Politik, Pembentukan organisasi masyarakat, Pendaftaran dan verifikasi peserta Pemilu, Hak memilih dan dipilih masyarakat, Penataan dan Pemetaan Dapil, Pencalonan, Logistik, Kampanye, Pemungutan, Perhitungan dan Rekapitulasi Suara, Penyelesaian Sengketa Hasil Pemilu, Penetapan perolehan kursi, Audit dan
Laporan Hasil Pemilu. Indikator baru yang dikembangkan adalah perencanaan program dan anggaran, sosialisasi, kualitas logistik, pendaftaran dan verifikasi peserta pemilu dan audit laporan hasil pemilu

Dari latar belakang diatas, maka penelitian ini membahas permasalahan yaitu (1) Indikator yang mempengaruhi kualitas pemilu (2) Instrumen penilaian Kualitas Pemilu di Indonesia. Penelitian ini bertujuan untuk menjelaskan aspek yang mempengaruhi kualitas pemilu dan aspekaspek yang luput dalam kerangka penyelenggara dan penilaian kualitas pemilu di Indonesia.

Penelitian ini menambah kekayaan teori penilaian kualitas Pemilu karena ada penyesuaian dengan kondisi Indonesia. Perubahan ini sangat penting karena keakuratan penilaian kualitas Pemilu berkurang, jika indikator yang dibangun tidak sesuai dengan nilai-nilai realitas di lapangan. Selain itu dengan metode penilaian yang logis, mudah diterapkan, dipahami, dipetakan dan dihitung akan dapat membandingkan kualitas pemilu satu negara dari waktu ke waktu dan perbandingan kualitas pemilu antar negara.

\section{PEMBAHASAN}

\section{Indikator yang mempengaruhi kualitas pemilu di Indonesia}

Indikator yang mempengaruhi kualitas Pemilu di Indonesia dibagi menjadi pra Pemilu, saat Pemilu dan Pasca Pemilu berdasarkan pengembangan penelitian yang dilakukan Eklit\&Reynold (2005) dan IDEA (2001). Indikator baru yang dikembangkan dari penelitian sebelumnya yaitu perencanaan program dan anggaran, sosialisasi, kualitas logistik, pendaftaran dan verifikasi peserta pemilu dan audit laporan hasil pemilu. Sedangkan prinsip yang harus dimiliki dalam setiap proses tahapan Pemilu adalah prinsip transparansi, integritas, kebebasan, kesamaan, keadilan dan keamanan. 
Pada Pra Pemilu, tujuh Aspek Kualitas Pra Pemilu dilihat dari kerangka hukum, Sistem Pemilu, Pembentukan Badan Penyelenggara Pemilu, Perencanaan Program dan Anggaran, Sosialisasi, Pembentukan Partai Politik dan Pembentukan organisasi masyarakat. Seluruh aspek dikaji berdasarkan indikator secara rinci.

Kerangka hukum Penyelenggara yang dibentuk harus jelas, terbuka, mengkomodir kode etik, keterjaminan hak suara masyarakat dimata hukum, tepat waktu, tidak tumpang tindih dengan aturan lain dan telah dilakukan uji publik.

Permasalahan hukum Pemilu 2019 (Hantoro, 2018) perlu dicermati adalah Uji materi PKPU no. 20 Tahun 2018 tentang pencalon anggota legislatif, uji materi UU Pemilu nomor 67/PUU-XVI/2018 mengenai persyaratan bakal calon, Sinkronisasi ketentuan pidana mahar politik dalam UU Pemilu dengan UU no. 10 Tahun 2016 karena hanya mengatur larangan mahar politik tapi tidak mengatur ketentuan pidananya. Permasalahan kerangka hukum ini akan mengurangi kualitas Pemilu karena kerangka hukum yang dibentuk tidak menjamin kebebasan masyarakat dimata hukum sehingga perlu dilakukan uji publik.

Sistem pemilu harus sesuai dengan peraturan yang berlaku dan harus menampung tingkat keterwakilan perempuan, minoritas politik, agama atau etnis dalam sistem Pemilu. Sesuai dengan penelitian dilakukan oleh Carter (2010) bahwa sistem pemilihan menggunakan prinsip proporsionalistas, representasi perempuan dan minoritas. Sementara di Indonesia masyarakat pluralisme dan heterogen menjadikan budaya politik identitas berdasarkan agama dan etnis, sehingga perlu adanya sistem pemilu yang mengakomodir seluruh lapisan masyarakat Indonesia.

Badan penyelenggara Pemilu harus memiliki struktur organisasi sesuai dengan hukum, Tim seleksi penyelenggara Pemilu memiliki kapasitas, profesional dan independen. Perekrutan penyelenggara Pemilu transparan, sesuai aturan dan kode etik, imprasialitas, integritas, profesionalisme dalam menyelenggarakan pemilu, tingkat kompetensi, ketepatan waktu pelaksanaan tugas. Keseluruhan indikator tersebut berguna untuk membentuk penyelenggara yang berkompeten, berkualitas dan berintegritas. Sesuai eklit \& Reynold (2005) dan IDEA (2001) bahwa penyelenggara pemilu yang independen, profesional dan berintegritas merupakan hal utama untuk mewujudkan kualitas Pemilu.

Data Indeks Kerawanan Pemilu tahun 2015 menyatakan bahwa profesionalitas penyelenggara menunjukan kerawanan diatas rata-rata pada bobot tertinggi disebabkan oleh ketersediaan anggaran, akurasi DPT, keterbukaan informasi penyelenggara tidak memadai Sedangkan tahun 2017 dimensi penyelenggaraan memiliki kerawanan tertinggi adalah aspek integritas dengan bobot 4 dan profesionalitas, dengan bobot 3,8. Dari hasil penelitian yang dilakukan oleh Bawaslu tersebut, menunjukan bahwa titik kerawanan dari profesionalitas, integritas dan keterbukaan informasi pada penyelenggara perlu dinilai untuk mengukur kualitas Pemilu di Indonesia.

Dalam membuat rencana kerja dan anggaran, tingkat efektifitas, efisiensi, kesesuaian aturan dan transparansi sangat dibutuhkan. Dalam pelaksanaanya rencana kerja dan anggaran dibentuk melalui Bottom-up namun realita terjadi anggaran yang turun sesuai dengan perencanaan tingkat atas. Hal ini akan memunculkan persoalan adanya kelebihan anggaran atau anggaran yang tidak sesuai dengan kebutuhan satuan kerja didaerah. Sesuai hasil penelitian yang dilakukan oleh Halyb,dkk. (2017) bahwa perencanaan anggaran KPU Kabupaten Konawe, secara Top down menyebabkan kesulitan dalam penyerapan anggaran dan memicu 
kurangnya kesadaran dan keterikatan anggaran dengan penerima kewenangan KPA.

Kualitas Pemilu dari sudut pandang sosialisasi dilihat dari efektifitas dan efisiensi sosialisasi, tingkat ketepatan waktu dan keterlibatan media masa. Sosialisasi berpengaruh kepada peningkatan informasi dan sekaligus menjadi sarana pendidikan politik masyarakat. Sesuai dengan kajian Gleko. Dkk (2017), bahwa sosialisasi digunakan oleh KPU untuk meningkatkan partisipasi Politik Masyarakat pada Pemilihan Umum kepala daerah.

Kualitas Pemilu sangat dipengaruhi oleh Kualitas Partai Politik. Partai politik yang berkualitas apabila dibentuk sesuai aturan, memiliki tugas pokok dan fungsi, kode etik, kaderisasi politik jelas dan terbuka. Hal tersebut menjamin terlaksananya pendidikan politik dan transparansi pelaksanaan anggaran sehingga partai politik yang dibentuk berkualitas dan berintegritas.

Sesuai dengan penelitian yang dilakukan oleh Dwipayana (2005) bahwa politik uang dan mahar politik kerap dilakukan oleh partai politik disetiap tahapan sehingga mengurangi integritas Pemilu, dengan menggunakan jasa partai calon kepala daerah mengeluarkan dana minimal 7-8 miliar rupiah, sehingga muncul transaksional politik melibatkan calon, partai dan stakeholder.

Hasil indek kerawanan Pemilu (IKP) Bawaslu tahun 2015 dan tahun 2017 menunjukan indeks kerawanan tinggi kampanye disebabkan oleh politik uang. Permasalahan mendasar dari temuan diatas adalah partai politik tidak mampu untuk melaksanakan tanggungjawabnya untuk memberikan integritas, etika dan transparansi kampanye dan pendidikan politik sehingga memunculkan kasus politik uang. Sehingga perlu adanya pengukuran kualitas Pemilu dari penyelenggaraan partai politik.
Pemilu yang berkualitas tidak dapat terlepas dari peran masyarakat sipil yang memantau pelaksanaan pemilu dan berpasrtisipasi dalam menyukseskan Pemilu. Organisasi masyarakat yang baik dapat dilihat dari tingkat independensi kader, kesesuaian antara luas lokasi dan pemantauan, kesesuaian antara rencana dan anggaran kerja, memiliki kompetensi dalam memantau pemilu.

Sesuai pendapat Ramadhanil (2015) bahwa partisipasi warga negara dibutuhkan untuk membangun dan memperbaiki sistem pemilu yang adil. Tujuh aspek masa pemilu dibangun untuk melihat kualitas Pemilu adalah pendaftaran dan verifikasi peserta pemilu, hak memilih dan dipilih masyarakat, penataan dan pemetaan Dapil, Pencalonan, Logistik, Kampanye, Pemungutan, Perhitungan dan Rekapitulasi Suara.

Indikator kualitas Pemilu adalah tingkat transparansi, kesesuaian aturan, objektivitas verifikasi partai politik, terlaksananya kegiatan sosialisasi, uji publik terhadap verifikasi partai politik, menampung tanggapan masyarakat dalam pembentukan DCS dan DCT, memenuhi prinsip kesetaraan keterwakilan perempuan dalam pencalonan (30\%), keterwakilan kaum disabilitas dan marginal.

Terdapat ketidak sesuaian antara aturan KPU dengan prinsip demokrasi, yaitu PKPU nomor 231/PL.03.1Kpt/06/KPU/XII/ 2017 tentang petunjuk teknis standar kemampuan jasmani dan rohani serta standar pemeriksaan kesehatan jasmani dan rohani dan bebas narkoba Pemilihan Gubernur, Wakil Gubernur, Bupati, Wakil Bupati dan Walikota dan Wakil Walikota, yang dinilai diskriminasi terhadap kaum disabilitas.

Sesuai kajian Carter (2014) bahwa Pemilu yang berkualitas menggunakan prinsip Kebebasan Diskriminasi, kesetaraan kaum minoritas, dan disabilitas. Kajian terdahulu tidak memasukan indikator keterwakilan kaum 
marginal dan disabilitas dalam indikator pencalonan peserta Pemilu, sehingga ini menjadi faktor yang wajib dipertimbangkan untuk menjaga pemilu dari prinsip bebas dan adil.

Indikator yang digunakan untuk melihat kualitas pemilu dalam hak memilih dan dipilih adalah tingkat kapasitas petugas pendaftaran, terselenggaranya sosialisasi dan pendidikan pemilih, sosialisasi kampanye, keakuratan dan transparansi dan kesesuaian Daftar Pemilih Tetap dengan aturan, akomodasi pemilih disabilitas, dan marginal dalam daftar pemilih, transparansi dan kemudahan akses daftar pemilih, keandalan sistem informasi pendaftaran pemilih, tingkat kemanan data pribadi pemilih.

Menurut Sehat (2015) Prinsip yang digunakan dalam pemilu yang berkualitas adalah kebebasan memilih dan dipilih, dan kebebasan disriminasi. Pada aturan KPU nomor 231 tahun 2017 sebagaimana yang telah dijelaskan sebelumnya, perlu dibentuk indikator untuk mengakomodir hak kaum disabilitas dalam pencalonan dan pemilihan.

Kualitas penataan dan pemetaan Dapil dapat dilihat dari indikator tersedianya aturan memenuhi prinsip kesetaraan suara, batasan daerah memiliki kekhasan geografis, tingkat netralitas dan profesional penyelenggara dalam penetapan Dapil, tingkat kesesuaian aturan, terselenggaranya uji publik oleh stake holder, tingkat penerimaan Dapil oleh publik dan terselenggaranya pengumuman dapil secara luas.

Menurut Sindikasi Pemilu dan Demokrasi (2016) prinsip penataan Dapil adalah homogenitas (kesamaan pandangan kelompok masyarakat), stabilitas (tingkat kemampanan keanggotaan konstituen), voluntary (masuk dan keluarnya partai baru). Jika dianalisa PKPU RI nomor 18/PP.02$\mathrm{Kpt} / 03 / \mathrm{KPU} / \mathrm{I} / 2018$ tentang petunjuk teknis penataan daerah Pemilihan dan alokasi kursi DPRD Kab/Kota telah menggunakan prinsip kesetaraan nilai suara, ketaatan pada sistem pemilu yang proporsional, prinsip integritas wilayah, prinsip berada dalam wilayah yang sama, prinsip kohesivitas dan kesinambungan.

Kualitas proses pencalonan dapat dilihat dari terselenggaranya sosialisasi, pengumuman, help desk pendaftaran dan verifikasi calon, tingkat profesionalitas penyelenggara dalam pendaftaran dan verifikasi calon, kesesuain aturan dengan uji publik dan menindak lanjuti masukan dari masyarakat.

Menurut Hantoro (2018) terdapat 4 permasalaham hukum pada tahapan pencalonan Pemilu 2019, yaitu uji materi PKPU nomor 20 tahun 2018, uji materi UU Pemilu tentang persyaratan bakal calon, potensi permasalahan pidana, implikasi putusan MK mengenai larangan pengurus parpol menjadi anggota DPD. Hal ini mengkindikasikan bahwa kualitas Pemilu dapat berkurang karena menghasilan potensi permasalahan hukum, dan terlambatnya pelaksanaan pencalonan. Sehingga indikator kesesuaian aturan dan uji publik harus dimasukan sebagai indikator kualitas pencalonan.

Kualitas logistik Pemilu dapat dilihat dari aspek kesesuaian standar harga pengadaan, distribusi logistik dan kesesuaian antara anggaran dan kebutuhan real, tingkat transparansi pengadaan, ketepatan waktu, jumlah, kualitas,sasaran pengadaan dan distribusi logistik, tingkat kemanan logistik, tingkat kesiapan gudang dan pengamana ekspedisi.

Seluruh indikator ini sesuai dengan Carter (2014) bahwa pemilu berkualitas jika melaksanakan transparansi dalam pengadaan, tidak berpihak dan menjaga keamanan. Selain itu menurut eklit \& Reynold (2005) bahwa disain kertas suara harus bebas dari diskriminasi dan memenuhi persyaratan hukum.

Kualitas kampanye dapat dilihat dari tingkat kesesuaian aturan kampanye 
dengan prinsip keadilan, penegakan hukum aturan kampanye, Tingkat praktik jual beli suara saat kampanye, idenpendensi media masa dalam kampanye, transparansi dan akuntabilitas dana kampanye, terlaksanaya juknis, sosialisasi, help desk, penyampaian pengumuman hasil laporan audit dana kampanye dan kesesuaian aturan pemilihan kantor akuntan publik.

Menurut Utari (2016), dalam tahapan kampanye sering terjadi money politik, uang ini sering dialihkan kepada keperluan dana kampanye, sehingga dana tersebut harus dilaporkan dalam laporan dana kampanye. Transparansi laporan keuangan partai politik sangat diperlukan untuk mengetahui transaksi yang tidak normal terjadi, sehingga penegakan aturan dan pengawasan kampanye perlu dimasukan menjadi indikator kualitas pemilu.

Indikator yang perlu dibangun adalah Tingkat Aksesibilitas TPS bagi pemilih penyandang disabilitas, Partisipasi Pemilih, Tingkat ketepatan waktu dan sesuai aturan, kompetensi Petugas penyelenggara pemilu ad-hoc, Integritas petugas penyelenggara terhadap praktik politik uang, efektivitas pengawasan proses pemilu, kebebasan atas kekerasan ,intimidasi, curang, politik uang, transparan dan ketepatan waktu, transparansi dan kualitas proses pemungutan dan rekapitulasi suara, dan tingkat keamanan dokumen pemilu.

Menurut Saleh (2005) bahwa dalam tahap pemungutan suara dan rekapitulasi suara, sering terjadi serangan fajar. Politik uang terjadi antara calon tertentu dengan penyelenggara. Namun, Undang-undang pemilu tidak mengatur politik uang dalam rekapitulasi suara. Pembuktian sendiri sulit dilakukan karena kerahasiaan pilihan suara pemilih dijamin oleh konstitusi. Sehingga perlu indikator kualitas Pemilu diatas dengan pengawasan dan hukum yang tidak memihak,tegas dan jelas.
Kualitas pasca Pemilu dapat dilihat dari 2 aspek, yaitu penyelesaian sengketa hasil pemilu, penetapan perolehan kursi dan laporan hasil Pemilu.

Pemilu semakin berkualitas jika sedikit jumlah gugatan hukum pada penyelenggara Pemilu, tingkat kredibilitas dan akurasi bukti dan kecepatan kesigapan menindak lanjuti hasil putusan akan meningkatkan kualitas Pemilu. Tingkat keadilan dalam penyelesaian sengketa Pemilu akan mempengaruhi kualitas Pemilu.

Indikator penilaian kualitas perolehan kursi dinilai dari tingkat kesesuaian antara penetapan perolehan kursi dan calon terpilih, terselenggaranya penetapan perolehan suara parpol dan tingkat ketepatwaktuan pembuatan laporan tahapan Pemilu. Indikator laporan hasil Pemilu yang berkualitas dilihat dari Dokumentasi dan Laporan diadministrasikan dengan baik, Kemanan dokumentasi dan keterbukaan informasi ke publik.

Menurut Surbakti (2008), bahwa penegakan hukum dan administrasi pemilu sangat penting dalam mewujudkan pemilu yang demokratis. Ketika terjadi gugatan hukum maka laporan hasil pemilu merupakan alat bukti yang kuat untuk menyelesaikan permasalahan hukum.

Sedangkan menurut Eklit \& Reynolds (2005) audit hasil pemilu merupakan salah satu indikator penting untuk menilai pemilu yang berkualitas atau tidak, sehingga indikator ini sangat krusial dan perlu diterapkan di Indonesia. Pada saat ini audit yang dilakukan terfokus kepada audit dana kampanye dan keuangan pemilu, namun audit proses tahapan dan laporan hasil pemilu belum dilaksanakan.

Sesuai dengan pendapat National Conference of State Legislatures (NCSL, 2019) bahwa audit proses pemilu berguna untuk memberikan informasi penyelenggara pemilu tentang segala kesalahan dalam sistem, dan dapat bertindak sebagai pencegah terhadap 
penipuan. Sedangkan audit pasca pemilihan berfungsi untuk mengevaluasi prosedur dan peralatan yang digunakan untuk menghitung suara selama pemilihan berjalan dengan baik, dan menghasilkan hasil yang benar.

\section{Penilaian kualitas Pemilu di Indonesia.}

Penilaian kualitas Pemilu dalam artikel ini dibangun untuk mengkaji metode tepat dalam pengukuran kualitas Pemilu. Penilaian kualitas Pemilu di Indonesia dilakukan oleh Zeni (2014) dengan pendekatan participatory assessment dan Bawaslu (2014, 2017, 2018) menggunaakan metode Analytical Hierarchy Process (AHP), sedangkan penilitian dengan metode kuantitatif dan deskriptif dilakukan oleh Eklit \& Reynolds (2005). Dalam penelitian ini penilaian kualitas Pemilu yang dibangun mengembangkan penelitian yang dilakukan oleh (Eklit \& Reynolds, 2005) dan model IDEA (2001) karena model ini cocok dengan tujuan penelitian mengkaji kualitas proses tahapan pemilu sehingga mudah diterapkan, dipahami, dipetakan dan dihitung.

Menurut IDEA (2002) pendekatan penilaian kualitas pemilu dapat dilakukan melaui polling opini publik, jejak pendapat dan exit pool. Jejak pendapat dapat dijadikan pendekatan paling tepat di Indonesia, karena wilayah yang luas, bentuk geografis, dan masyarakat yang heterogen membuat pendekatan polling publik dan exit pool tidak efektif.

Metode jejak pendapat dapat berguna untuk melacak persepsi populer dari proses pemilu dan persepsi tenaga ahli tentang kesesuaian proses tatakelola pemilu dengan aturan yang berlaku.

Exit pool tidak digunakan karena tidak sesuai dengan azaz Pemilu Langsung Umum Bebas Rahasia, kerahasiaan data suara yang diberikan masyarakat dapat diketahui langsung secara nasional. Sedangkan metode opini publik tidak efektif dilakukan karena Jejak pendapat membutuhkan waktu, biaya yang besar dan kegiatan yang secara logistik kompleks, sehingga tidak cocok dengan keadaan geografis dan heterogenitas masyarakat Indonesia.

Penilaian kualitas Pemilu diberikan oleh pihak yang terlibat dan memahami pemilu, yaitu tenaga ahli/pakar/dosen, organisasi masa, partai politik, Badan Pengawas, Inspektorat, KPU dan media massa.

Penilaian dibuat dengan scoring pada skala nilai tertentu atas indikator digunakan sebagai instrumen kualitas pemilu pada 3 tahapan pelaksanaan pemilu pra, masa dan pasca pemilu.

Pada tahap pengumpulan data, dilakukan dengan questioner dan pengumpulan peraturan terkait terhadap nara sumber yang dipilih berdasarkan keterlibatannya secara aktif baik sabagai penyelenggara, peserta dan pemantau sehingga memiliki informasi yang dibutuhkan dalam rangka evaluasi.

Teknik analisis data yang digunakan adalah skala ordinal yaitu nilai berdasarkan rengking yaitu: 3: sangat baik, 2: baik, 1: buruk, 0: sangat buruk (Eklit, Reynold,2005). Skala ordinal dipilih karena dengan menggunakan skala ordinal dapat merepresentasikan pendapat ahli atau nara sumber dan dikonversi ke angka sehingga dapat menciptakan tingkat kualitas pemilu, sebagai dasar evaluasi dan perbandingan setiap periode.

Untuk menguji validitas indikator kualitas pra, masa dan pasca pemilu terhadap kualitas pemilu, maka dapat dilakukan validasi kontruk (Arikunto, 2006). Sedangkan untuk melihat adanya hubungan antara indikator kualitas pra, masa dan pasca pemilu terhadap kualitas Pemilu secara keseluruhan, digunakan alat ukur korelasi product moment.

\section{SIMPULAN}

Aspek yang mempengaruhi kualitas pemilu di Indonesia adalah aspek pra 
pemilu meliputi kerangka hukum Pemilu, sistem Pemilu, Pembentukan badan penyelenggara pemilu, perencanaan program dan anggara, sosialisasi, pembentukan partai politik dan organisasi masyarakat. Sedangkan aspek masa pemilu meliputi aspek pendaftaran dan verifikasi peserta pemilu, hak memilih dan dipilih masyarakat, penataan dan pemetaan Dapil, Pencalonan, Logistik, Kampanye, Pemungutan dan Perhitungan dan rekapitulasi suara. Aspek pasca pemilu meliputi penyelesaian sengketa hasil pemuli, penetapan perolehan kursi serta audit dan laporan hasil pemilu. Keseluruhan aspek tersebut memenuhi prinsip yang menganut prinsip kesetaraan, kebebasan, keadilan, transparansi, profesionalitas dan integritas dan penyesuaian budaya politik lokal. Aspek yang luput dalam kerangka penyelenggara dan penilaian kualitas pemilu di Indonesia adalah penyesuaian budaya politik lokal dan memasukan indikator kebebasan diskriminasi terhadap masyarakat disabilitas dalam pencalonan peserta pemilu.

Penilaian kualitas Pemilu dibangun sebagai dasar untuk pengkajian penelitian selanjutnya, dengan metode kuantitatif dengan skala pengukuran ordinal, pengumpulan data melalui questioner akan mudah diterapkan, dipahami, dan dihitung sehingga dapat membandingkan kualitas pemilu satu negara dari waktu ke waktu dan perbandingan kualitas pemilu antar negara.

\section{DAFTAR PUSTAKA}

Dwipayana, A. (2005). Cost of Democracy di Tiga Kabupaten, Yogyakarta: Laboratorium Jurusan Ilmu Pemerintahan Fisipol UGM, 2005

Alemika, E.E.O. (2007). Quality of Elections, Satifaction With Democracy And Political Trust In Africa.Afro Barometer Working Paper.Church Square:Afro Barometer

Arikunto, S. (2002). Prosedur Penelitian Suatu Pendekatan Praktek. Jakarta: Rineka Cipta.

Badan Pengawas Republik Indonesia. (2015).Indek kerawanan Pemilu pada Pilkada 2015. Jakarta: Bawaslu RI
Badan Pengawas Republik Indonesia. (2014).Laporan Hasil Pengawasan Pemilu Presiden dan Wakil Presiden tahun (2014). Jakarta: Bawaslu RI

Bawaslu RI. (2018). Indeks Kerawanan Pemilu 2018. Jakarta: Bawaslu RI

Carter, D. (2010). Electoral Systems and Election Management. diunduh di https://www. researchgate.net/ publication/237654779 tanggal 8 Oktober 2018

Darnolf, S. Ellena, K. Lippolis, E. Shein, E \& Vickery, C.(2015). Election Audits: International Principles That Protect Election Integrity. Washington: International Foundation For Electoral System (IFFS)

Eklit, J \& Reynolds, A. (2005) .Framework for the Systematic Study of Election Quality. Democratization. 12 (2): 147-162

Gleko, P. Suprojo, A. \& Lestari, A.W. (2017). Strategi Komisi Pemilihan Umum Dalam Upaya Meningkatkan Partisipasi Politik Masyarakat Pada Pemilihan Umum Kepala Daerah. Jurnal Ilmu Sosial dan Ilmu Politik. 6 (1): 38-47

Hantoro, N.M. (2018). Permasalahan hukum pada tahap pencalonan Pemilu 2019. Pusat penelitian Badan Keahlian DPR RI.X (16):1-6

Halyb, A.F. Liando, D.M. Mamentu, M.. (2017). Akuntabilitas Pengelolaan Keuangan Komisi Pemilihan Umum Kabupaten Konawe. Tesis. Tata Kelola Pemilu Pasca Sarjana Unsrat.

Hirano, S. \& Synder Jr. M, James. (2014). Primary Elections and the Quality of Elected Ocials. Paper. Columbia University \& Harvard University.

International Institute for Democracy and Electoral Assistance (IDEA). (2001). Standar-standar internasional untuk Pemilihan Umum. Sweden: Bulls Tryckeri

Mozaffar, S. \& Schedler, A. (2002). The Comparative Study of Electoral GovernanceIntroduction. International Political Science Review. 23(1): 5-27

Norris, P. Frank, R. Martinez, F. (2013). "Assessing The Quality of Election". Journal of Democracy. 24 (4):124-135

National Conference of State Legislatures (2019). Post Election Audit. Diunduh di http://www.ncsl.org/research/electionsand-campaigns/post-electionaudits635926066.aspx tanggal 05 Januari 2019

Rexha, B. Murturi, I. Shabani, I. \& Rexhepi, A. (2016). Improving Quality of Election Process Using Crowdsourcing Techniques. International Journal of Applied Mathematics,Electronics and Computers. 4(4):107-112

Ramadhanil, dkk. (2015). Desain Partisipasi Masyarakat Dalam Pemantauan Pemilu". 
Lati Praja Delmana, Aidinil Zetra, \& Indraddin. Konstruksi Indikator dan Formula Penilaian Kualitas

Handbook. Kemitraan Pembaharuan Tata Pemerintahan di Indonesia

Sehat, C.M. (2015). Observing (And Assessing) The Good Election New Approaches To Electoral Obligations And Integrity From The Carter Center.The carter center.Electoral Risk Management Conference.The carter center

Sindikasi Pemilu dan Demokrasi. (2016). Problematika Pemetaan dan Pembentukan Peta Daerah Pemilihan Pemilu Indonesia.Jakarta:Media Sindikasi Pemilu dan Demokrasi

Surat Keputusan Komisi Pemilihan Umum nomor 231/PL.03.1-Kpt/06/KPU/XII/2017 tentang Petunjuk TeknisStandar Kemampuan Jasmani dan Rohani serta Satandar Pemeriksaan Kesehatan Jasmani, Rohani dan Bebas Penyalahgunaan Narkotika dalam Pemilihan Gubernur dan Wakil Gubernur dan Wakil Bupati, dan/atau Walikota dan Wakil Walikota

Surbakti, R. Supriyanto, D. Santoso, T. (2008). "Perekayasaan Sistem Pemilihan Umum
Untuk Pembangunan Tata Politik Demokratis". Jakarta: Kemitraan bagi Pembaharuan Tata Pemerintahan di Indonesia

Saleh, T. (2006). Surplus atau defisit demokrasi? Pilkada dibanyak daerah"Opini Jawa Pos. 8 Juni 2006

The Carter Center. (2014). Election Obligations and Standards a Carter Center Assessment Manual. Handbook. Atlanta: One Copenhill

The Ace Electoral Knowledge Network. (2014). Measuring the Quality of Election.Diunduh di http://aceproject.org/ aceen/focus/measuring-electoralquality.tanggal 7 Oktober 2018.

Utari, I.S. (2016). Pencegahan Politik Uang dan Penyelenggaraan Pilkada yang berkualitas: Sebuah Revitalisasi Ideologi.Seminar Nasional Hukum. 2 (1):451-474

Zein, K. (2014). Laporan Evaluasi Pemilu 2014. Jakarta: Lembaga Penelitian Pendidikan Penerangan Ekonomi Sosial (LP3ES). 